\title{
Faith and Killing in the US Army in the Second World War: Some Perspectives from the European Theatre of Operations
}

\author{
Michael Snape
}

Challenging the mythology of the 'Greatest Generation,' this article examines the conduct of American combat soldiers in North Africa and Europe during the Second World War. Although the ferocity and barbarity of America's Pacific War is widely recognised and attributed, at least in part, to the cultural and racial cleavages between America and Japan, the treatment of German and Italian soldiers by American ground troops invites greater examination. Here the religiously susceptible products of a largely Christian and even pacifist society, who went on to comprise a generational pillar of American religious life in the second half of the twentieth century, often behaved with a ruthlessness that shocked contemporary observers, including many of their own chaplains. In the absence of a racial and cultural chasm between the antagonists, this article examines the catalysts and patterns of this behaviour and exposes the fragility of traditional moral constraints in the context of America's much-vaunted 'good' war.

'Greatest Generation', combat, morality, atrocity, Christianity, chaplains, veterans, just war.

Michael Snape is the Michael Ramsey Professor of Anglican Studies at Durham University and has published widely on religion and war in the Anglophone world.

In October 2015, and when discussing his new book Ardennes 1944 at the Cheltenham Literature Festival, historian Antony Beevor argued that war crimes committed by US soldiers during the Second World War, and most notably the shooting of prisoners of war, had been 'overlooked by US historians because no one dares to challenge the reputation of "the Greatest Generation". ${ }^{1}$ Taking this report in the London Times at face value, this verdict is simply wrong, and scarcely qualifies as 'news'. Military historians - Americans among them - have for many years scrutinised the conduct of GIs during the Second World War, and have highlighted the often brutal treatment they meted out to enemy combatants and even civilians. ${ }^{2}$ In fact, an unmistakeable anti-German animus among GIs in the

1 The Times, 3 October 2015, 17.

2 See, for example, Gerald F. Linderman, The World within War: America's Combat Experience in World War II (New York: Free Press, 1997); Peter Schrijvers, The Crash of 
immediate aftermath of the war lent some plausibility to James Bacque's assertion, in his 1989 book Other Losses, that 800,000 German prisoners of war died in American captivity. However erroneous and controversial such claims were, longstanding recognition of American brutality and vengefulness has scarcely dented the popular mythology of the United States and the Second World War, a mythology which still clings to the perception of a 'good war' (perhaps, in light of Korea and Vietnam, America's only good war of the twentieth century), and to the unparalleled achievements of the generation that survived the Great Depression, vanquished Hitler, Hirohito, and Mussolini, and overcame the Soviet Union in the Cold War. As Stephen E. Ambrose, their most influential praisesinger, insisted in his 1997 book Citizen Soldiers, a study of the US Army from the aftermath of D-Day to the end of the war in Europe:

The 'we' generation of World War II (as in 'We are all in this together') was a special breed of men and women who did great things for America and the world... they were the children of democracy and they did more to help spread democracy around the world than any other generation in history... and we all of us, living and yet to be born, must be forever profoundly grateful. ${ }^{3}$

What Ambrose omitted to mention was that this was also a conspicuously religious generation of Americans, a point made the following year in Tom Brokaw's multi-biography The Greatest Generation:

FAITH IN GOD [wrote Brokaw] was not a casual part of the lives of the World War II generation. The men and women who went off to war, or stayed home, volunteer that their spiritual beliefs helped them cope with the constant presence of possible death, serious injury, or the other anxieties attendant to the disruptions brought on by war... On the front lines, chaplains were not incidental to the war effort. Some jumped with the Airborne troops on D-Day and others risked their own lives to administer last rites or other comforting words to dying and grievously wounded young men wherever the battle took them. The very nature of war prompted many who participated in it to think more deeply about God and their relationship to a higher being once they returned home. ${ }^{4}$

More than a decade later, in American Grace (2010), a comprehensive study of American religious life since the 1960s, Robert D. Putnam and David E. Campbell corroborated Brokaw's assertion that piety was another distinguishing feature of

Ruin: American Combat Soldiers in Europe During World War II (New York: New York University Press, 1998); Michael Burleigh, Moral Combat: A History of World War II (London: HarperPress, 2010).

3 Stephen E. Ambrose, Citizen Soldiers: The U.S. Army from the Normandy Beaches to the Bulge to the Surrender of Germany, June 7 1944-May 7, 1945 (New York: Simon \& Schuster, 1998). 472-73.

4 Tom Brokaw, The Greatest Generation (New York: Random House, 1998), 55. 
the 'Greatest Generation'. As Putnam and Campbell noted, 80 per cent of American men born in the 1920s 'served in the military in World War II', and the effects for American religious life were profound and far-reaching:

It was this GI generation who as young husbands and fathers, together with their wives, led the surge to church in the late 1940s and 1950s [and] this cohort would remain unusually observant for the rest of their lives. Throughout all the shocks and aftershocks of the ensuing half century and even into the next millennium the GIs and their wives and widows would form the bedrock of American religious institutions... ${ }^{5}$

Although much (far too much) has been made of the contemporary adage that 'there are no atheists in foxholes', it must be stressed that the religious nature of American society meant that very few infidels climbed into them in the first place. While levels of church membership and churchgoing suffered in the Depression era, ${ }^{6}$ and although the US Army and Navy was wary for constitutional and political reasons of collecting and publishing official statistics on religious affiliation, contemporary observers noted how very few recruits were declared non-believers - 'perhaps not one in a thousand', according to one senior chaplain at Great Lakes Naval Training Station. ${ }^{7}$ Institutional religion enjoyed a hugely privileged place in America's armed forces, notwithstanding the 'establishment' clause of the First Amendment, and a mass of statistical and anecdotal evidence indicates a strengthening of belief in God as a result of combat experience in the US Army. In fact, a survey conducted among hundreds of combat veterans in December 1945 indicated that four-fifths of them felt that their 'Army experience increased faith in God'. ${ }^{8}$ And it is the relationship between the burgeoning faith and frequent brutality of this generation of American front-line soldiers that this paper will explore, viewing this subject largely (but not exclusively) through the eyes of their chaplains, the Army's religious professionals, and in the illuminating context of the American ground war in the West, which formed the major part of Eisenhower's much-vaunted 'Crusade in Europe'.

Before proceeding, and again pace Beevor, it is worth emphasising that there have been clear signs of a slow shift in upper-end Hollywood depictions of the Second World War as it was experienced by GIs in Europe. Inspired by the fiftieth

5 Robert D. Putnam and David E. Campbell, American Grace: How Religion Divides and Unites Us (New York: Simon and Schuster, 2010), 85.

6 Robert T. Handy, "The American Religious Depression, 1925-1935", in: Church History 29, 1 (1960), 3-16.

7 John E. Johnson, "The Faith and Practice of the Raw Recruit", in: Willard Learoyd Sperry (ed.), Religion of Soldier and Sailor (Cambridge, MA: Harvard University Press, 1945), 45.

8 Samuel A. Stouffer et al, The American Soldier (Princeton: Princeton University Press, 1949), 2 vols, II, 187. 
anniversary of D-Day, and despite its comic-book ending, Stephen Spielberg's Saving Private Ryan (1998) was rightly acclaimed for its visceral portrayal of the battlefield, and especially for its depiction of the notorious carnage on Omaha Beach on 6 June 1944. Nor did this depiction shrink from portraying German soldiers seeking to surrender being shot out of hand. However, in a later scene in the film, an SS soldier is captured and, despite the entreaties of some of his men, released by Captain John H. Miller, as played by Tom Hanks - Hollywood's epitome of American decency. In a later Spielberg production, the HBO series Band of Brothers (2001), further concessions were made to the sterner realities of war, especially when an officer of the $101^{\text {st }}$ Airborne Division was shown distributing cigarettes to an unsuspecting group of German prisoners - before mowing them down with his tommy-gun. However, in the subsequent reaction of the soldiers of Easy Company, it is implied that such conduct was a shocking aberration - the action of a ruthless maverick which is neither condoned, nor even believed, by more typical GIs. In comparison, the depiction of a similar scene in David Ayer's Fury (2014), which is purely a work of fiction, is much franker in its depiction of calculated brutality, group indifference, and even active collusion in the summary shooting of prisoners. Perhaps the shift is generational. However candid in certain respects, Spielberg's productions are the work of a film-maker born in 1946 to a Jewish-American father who volunteered to serve in the US Army's Signal Corps in the Second World War. ${ }^{9}$ In contrast, David Ayer was born in 1968, served as a submariner in the US Navy, and is the grandson of Second World War veterans. ${ }^{10}$ In addition to providing critical distance from the prevailing presentation of America's war generation, the passage of time has eroded another taboo - namely the admission of any sense of German victimhood during the Second World War. In this respect, British historians have for some decades acknowledged the appalling human impact of area bombing in the Second World War ${ }^{11}$ Germans now speak more freely of the orgy of rape that accompanied the advance of the Red Army into eastern Germany; ${ }^{12}$ and Czechs acknowledge the brutal treatment suffered by ethnic Germans in Czechoslovakia in the wake of Germany's defeat. ${ }^{13}$ However revolting in themselves, the colossal crimes of the

9 Cf. Interview: Arnold Spielberg, available online at: http://oralhistory.rutgers.edu/ interviewees/30-interview-html-text/146-spielberg-arnold, [accessed 3 August 2017].

10 Cf. IMDb: David Ayer, available online at: http://www.imdb.com/name/nm00437 42/bio?ref_=nm_ov_bio_sm, [accessed 10 February 2016].

11 Max Hastings, Bomber Command (London: Joseph, 1979); Paul Addison / Jeremy A. Crang (eds), Firestorm: The Bombing of Dresden 1945 (London: Pimlico, 2006); Richard Overy, The Bombing War: Europe, 1939-1945 (London: Allen Lane, 2013).

12 Cf. BBC: The rape of Berlin, available online at: http://www.bbc.co.uk/news/ma gazine-32529679, [accessed 3 August 2017].

13 Cf. Puhl, Jan: "Newly Discovered Film Shows Post-War Executions", in: Spiegel Online, 02. June 2010, available online at: http://www.spiegel.de/international/europe/ 
Third Reich cannot wholly eclipse the fact that much more could be said and written on this subject, or that many members of America's 'greatest generation' were far from guiltless in this respect.

In 1986, John W. Dower's book War Without Mercy brought home to postVietnam America the atrocious conduct of both sides during the Pacific War - its sub-title, Race and Power in the Pacific War, stressing the fact that America's tendency to place 'a cheapness on the lives of Orientals', as John Kerry put it to the Senate Committee of Foreign Relations in $1971,{ }^{14}$ had a much longer pedigree than the Vietnam War. Indeed, a sense that the struggle against Japan was a very different kind of war had been rife during the conflict itself. For the American public, the appalling cruelty of the Japanese had been apparent since the 1937 Rape of Nanking (which had been filmed in part by an American missionary), and their depravity was simply confirmed by what President Roosevelt branded their 'unprovoked and dastardly' attack on Pearl Harbor four years later. In fact, there had been a very public row over the collection of Japanese skulls as trophies of war after Life magazine published a photograph of a navy officer's girlfriend posing with an autographed skull in 1944. Furthermore, a keen appetite for killing the Japanese was freely expressed by American servicemen, being roughly seven times greater in 1943, according to one army poll, than that for killing Germans. ${ }^{15}$ Such attitudes and conduct during the Pacific War help to place American transgressions in Europe in much starker relief. Despite scrimmages between US Navy warships and German U boats in the North Atlantic, Germany had not overtly attacked the United States prior to Hitler's declaration of war on 11 December 1941; German troops never occupied American territory; and, as far as American prisoners of war were concerned, the Germans usually respected the Geneva Convention, with the Malmédy massacre of December 1944 (perpetrated by the SS) being a stark deviation from this rule. ${ }^{16}$ Significantly, even JewishAmerican POWs were protected by its terms and, unlike the Pacific, US Army chaplains in Europe did not feel the need to be armed. More striking still, and while much has been made of the obvious racial dimensions and profound cultural cleavages of the Pacific War, a substantial minority of GIs in Europe were (like Eisenhower himself) of German descent, and American soldiers were confronting

massacre-in-czechoslovakia-newly-discovered-film-shows-post-war-executions-a-69806 0.html, [accessed 3 August 2017].

14 Cf. "Vietnam Veterans Against the War Statement by John Kerry to the Senate Committee of Foreign Relations", available online at: http://www2.iath.virginia.edu/ sixties/HTML_docs/Resources/Primary/Manifestos/VVAW_Kerry_Senate.html, [accessed 15 January 2018].

15 Stouffer et al, The American Soldier, II, 30-36.

16 Peter S. Kindsvatter, American Soldiers: Ground Combat in the World Wars, Korea, and Vietnam (Lawrence, KS: University Press of Kansas, 2003), 200-201. 
enemies who were for the most part (and at least nominally) Protestant or Catholic Christians.

Before proceeding, it is important to stress a very important point: for most American ground troops in the Second World War, killing was usually done impersonally, and at a distance. In the words of Harry P. Abbott of the $1^{\text {st }}$ Armored Division, a United Brethren chaplain, 'Only a small percentage of our soldiers, mostly in the infantry, pulled the trigger and saw a man crumple up. ${ }^{17}$ Again, and as the American war correspondent Eric Sevareid remarked, the Second World War battlefield was often eerily empty:

One felt baffled at first by the unreality of it all. Unseen groups of men were fighting other men that they rarely saw. They located the enemy by the abstractions of mathematics, an imagined science; they reported the enemy through radio waves that no man could visualize; and they destroyed him most frequently with projectiles no eye could follow. ${ }^{18}$

The remote and even clinical nature of this slaughter did not, of course, render it morally neutral. With reference to their high explosive violations of the Sixth Commandment, Abbott was keen to argue that the talent for destruction displayed by American artillerymen had no adverse effect upon its gunners, morally speaking. Reassuring his civilian wartime readers, Abbott insisted that they killed with regret, and rather nobly 'derived satisfaction from the realization that they helped to protect [the infantry], and to hasten the climax of the war, thus saving men on both sides'. ${ }^{19}$ Christian Scientist chaplain Richard H. Chase, another veteran of North Africa, echoed this comforting view. American gunners did not revel in their lethal work. Of a particularly skilful officer, Chase simply noted that his was a purely cerebral business, which largely consisted of keeping a level head and getting his calculations right. ${ }^{20}$

Nevertheless, fears about what to expect after the war, and especially from front-line soldiers, were rife in America's churches, and perhaps especially in the so-called Protestant 'mainline', which had widely embraced pacifism in the interwar years. Haunted by the gangsterism of the Prohibition era, and by the perceived role of First World War veterans in violent criminality (Al Capone had, significantly, claimed to have been wounded in France while fighting in the Argonne in 1918), respectable Americans naturally feared the long-term effects of a much longer war and a much vaster national mobilisation. Nevertheless, optimists in the churches predicted that the salutary effects of 'foxhole religion' would serve as a brake on the morally corrupting influences of front-line service-conditions in

17 Harry P. Abbott, The Nazi '88' Made Believers (Dayton, OH: The Otterbein Press, 1946), 121.

18 Eric Sevareid, Not So Wild a Dream (New York: Atheneum, 1976), 388.

19 Abbott, The Nazi '88', 121.

20 Ellwood C. Nance, Faith of Our Fighters (St. Louis, MO: Bethany Press, 1944), 36. 
which, as Christian Science chaplain Richard H. Chase observed, soldiers had not only become attuned to breaking the Sixth Commandment, but also the Eighth by helping themselves to whatever they needed. In 1945, a confident forecast to this effect was made by Southern Baptist army chaplain Charles H. Ashcraft from the battlefields of the Southwest Pacific. According to Ashcraft:

Out where men in a few moments age years into maturity, mentally and physically, the corresponding maturity of their religious experience cannot be logically questioned... A soldier lying out behind enemy lines wounded for twenty-four hours has plenty time for serious contemplation about religion. Those with such experiences do not easily depart from their decision. ${ }^{21}$

Towards the end of 1946, and with American society showing few signs of a mass and uncontrollable slide into veteran-driven criminality, it seemed to some as though this confidence had been well-placed. Writing to The Chaplain magazine, William Hints, a Methodist minister from Wyoming and a veteran of the First World War, rejoiced 'Thank God for the Tight Corners'. In his opinion, it stood to reason that the 'most valuable discoveries' were to be made in dangerous situations. There was, therefore, nothing at all to fear from the battlefield experiences of returned veterans, for those 'who have actually participated in the actual events of life at its most strenuous activity, and death in its irrecoverable reality', had ultimately 'plumbed the depths and scaled the heights of experience'. ${ }^{22}$

Conversely, and despite wartime fears of the corrupting and desensitizing effects of combat, in such a large citizen army it was inevitable that concern could also arise about a widespread reluctance to close with and kill the enemy. Audie Murphy, one of the US Army's most decorated and effective killers of the Second World War, while fully accepting that 'it is not easy to shed the idea that human life is sacred', was repeatedly perturbed by the inhibitions of others in this respect. On Sicily in 1943, Murphy was surprised to be rebuked for shooting a pair of fleeing Italian officers, and in Northwest Europe in the winter of 1944-45 he found himself remonstrating with another GI for refusing to administer the coup de grâce to a wounded German. ${ }^{23}$ These qualms were familiar to John T. Bassett, who served in Italy with the $10^{\text {th }}$ Mountain Division in Italy. One of his comrades, 'a quiet homely Dutchman', consistently volunteered for unpleasant fatigues - such as 'cleaning out greasy pots with lukewarm muddy water'- because, as he told Bassett, 'at least I'm doing something useful, which is better than killing, which is not' ${ }^{24}$ Bassett himself was no stranger to the greyness of his moral world:

21 The Chaplain, April 1945, 46.

22 The Chaplain, November 1946, 2-4.

23 Audie Murphy, To Hell and Back (New York: H. Holt, 1949), 11, 205-6.

24 John T. Bassett, War Journal of an Innocent Soldier (New York: Avon Books, 1991), 30. 
We thought the Krauts were evil; but we were evil too. I was prepared to kill a man, or men for a crime or crimes he or they may not have committed. Should it be right for me to kill a middle-aged Kraut who loved his family and believed in God, not in Hitler, but who was drafted by the Third Reich to serve his country? $?^{25}$

American army chaplains were certainly very familiar with this inner turmoil. Writing in a hospital in France in October 1944, Presbyterian Chaplain Alvin O. Carlson described GIs as 'young men with keen intellects, perfect physiques and enlarged vision - men who hated to kill more than to be killed. They had been taught in Sunday school and at their mothers' knees to love one another. ${ }^{26}$ Chaplain Abbott concurred, maintaining that the transition to the role of a trained killer was far from easy:

Our men do not like to kill, because of their education, their religious training, and lofty ideals; and no man, in his right sense, enjoys or relishes it... I do not believe that our men in the European Theatre cherished hatred in their hearts, except in those cases where they have seen their own buddies killed at the hands of the enemy... I have met some soldiers that seem to be indifferent toward human life. Theirs was only a grim determination to conquer the enemy regardless of the cost - they asked no quarter and gave none. They were consumed with a desire to even accounts by exterminating their enemys [sic]. But this type of man was the exception. ${ }^{27}$

No doubt deepened by the strongly pacifist zeitgeist that had gripped much of American Protestantism in the inter-war years, the problem of killing proved to be among the most common dilemmas presented to chaplains by GIs who sought their advice. Sailing for North Africa in November 1942, Presbyterian chaplain Eugene L. Daniel was keenly and even uncomfortably aware of the 'natural revulsion for killing even an enemy' that was felt by the soldiers of the $168^{\text {th }}$ Infantry Regiment, even on the eve of their first battle:

Few had an adequate idea about a 'Just War'. Early in the night of the landings at Algiers, Colonel Bear asked me to go into the hold of the ship with him and speak to his men. I told them that our going into battle was much like the situation when a mad dog was loose in our neighborhood. Hitler and the other Axis leaders were like mad dogs loose in the world community and we had to stop them even if we had to kill in order to do so. ${ }^{28}$

\footnotetext{
25 Ibid, 53.

26 Alvin O. Carlson, He Is Able: Faith Overcomes Fear in a Foxhole (Grand Rapids, MI: Zondervan, 1945), 76.

27 Abbott, The Nazi '88', 121.

28 Eugene L. Daniel, In the Presence of Mine Enemies: An American Chaplain in World War II German Prison Camps (Charlotte, NC: E.L. Daniel Jr, 1985), 7.
} 
These inhibitions were just as obvious among the draftees of the $88^{\text {th }}$ Infantry Division while training at Camp Gruber, Oklahoma. According to Southern Baptist chaplain Wallace M. Hale, being trained to kill could be profoundly unnerving:

Suddenly, one of our better young men is drafted into the military or perhaps he volunteers. He's immediately told that his job is killing. The killers he has known have been thugs in the news or in the artificial situation of the movies, but he is now being trained with a seriousness and lethality that shocks his innermost emotions and sensibilities. ${ }^{29}$

Based on his dealings with its officers and enlisted men, Hale eventually drew the conclusion that:

Roman Catholics, at this particular time, could bring themselves to accept a 'just' war, but I found that most Protestants were basically pacifistic. They hated war. They felt that war was sinful. They honestly considered that their participation in war was against their religious principles and yet most of them went on to war, and did a good job. ${ }^{30}$

In a telling illustration of what another chaplain termed stopping the moral clock for the duration of the war, ${ }^{31}$ one officer even told Hale 'Chaplain, when the war is over, I am going to get myself straightened out with God, and then I am going to live a Christian life... No man can fight a war and do what Christ taught him to do. ${ }^{32}$ Fully persuaded that most soldiers killed 'with a gnawing feeling underneath that this thing should not have taken place', Hale agreed with the post-war claim of the army combat historian S. L. A. Marshall that most GIs in the Second World War felt disinclined to fire their weapons - even in combat - due to the fact that 'an American ground soldier... is what his home, his religion, his schooling, and the moral code and ideals of his society have made him, ${ }^{33}$

However reassuring all this may have been to respectable civilian society during and after the war, this initial doubt and hesitation serves to throw the conduct of America's front-line warriors into even starker relief, for what impressed and unsettled Ernie Pyle, America's most famous war correspondent, was the speed with which so many GIs cast off these inhibitions once they had experienced their baptism of fire. Pyle, for example, noticed that the attitudes of American infantrymen quickly hardened, changed beyond recognition, over the months of the Tunisian campaign:

29 Wallace M. Hale, Battle Rattle (Allen, TX: Timberwolf Press, 2004), 35.

30 Ibid, 41.

31 The Link, March 1945, 25.

32 Hale, Battle Rattle, 41.

33 Ibid, 46; S.L.A. Marshall, Men Against Fire: The Problem of Battle Command in Future War (New York: William Morrow \& Co., 1947), 54, 78. 
The most vivid change was the casual and workshop manner in which they talked about killing. They had made the psychological transition from their normal belief that taking human life was sinful, over to a new professional outlook where killing was a craft. No longer was there anything morally wrong about killing. In fact, it was an admirable thing. ${ }^{34}$

Pyle added the significant rider, 'it hadn't been necessary for me to make that change along with them... killing to me was still murder' ${ }^{35}$ It even struck Pyle that the typical infantryman's appetite for killing the enemy, and so winning the war, now shaded into the insatiable:

He wanted to kill individually or in vast numbers. He wanted to see the Germans overrun, mangled, butchered in the Tunisian trap. He spoke excitedly of seeing great heaps of dead, of our bombers sinking whole shiploads of fleeing men, of Germans by the thousands dying miserably in a final Tunisian holocaust of their own creation... In that one respect the front-line soldier differed from all the rest of us... we [my italics] wanted terribly yet only academically for the war to be over. The front-line soldier wanted it to be terminated by the physical process of his destroying enough Germans to end it. He was truly at war. The rest of us, no matter how hard we worked, were not. ${ }^{36}$

Blooded and seasoned in North Africa, and long before the revelations of Dachau and elsewhere could introduce some dramatic exculpatory gloss, many American infantrymen in Italy and Northwest Europe could display a ruthlessness that slid ineluctably into the realm of the murderous. In Italy, for example, a British intelligence officer was disturbed to find that some GIs had been given direct orders that any German attempting to surrender should be beaten to death. ${ }^{37}$ After the breaking of the Gustav Line in the spring of 1944, Eric Sevareid stumbled across a pair of GIs in a shattered Italian village. Nearby, he noted, 'A young German soldier lay sprawled just inside a sagging doorway, his hobnailed boots sticking into the street', a scene that prompted an off-hand admission that he had paid the ultimate penalty for lagging behind - 'Thus casually was deliberate murder announced [wrote Sevareid, appalled] by boys who a year before had taken no lives but those of squirrel or pheasant. ${ }^{38}$ As Sevareid tellingly recalled, 'As weeks went by and this experience was repeated many times, I ceased even to be surprised only, I could never again bring myself to write or speak with indignation of the Germans' violations of the "rules of warfare." 39 In light of such scenes, it is ironic

34 Ernie Pyle and Orr Kelly, Here is Your War: Story of GI Joe (Lincoln, NE: University of Nebraska Press, 2004), 195.

35 Ibid.

36 Ibid, 195-96.

37 James Holland, Italy's Sorrow: A Year of War 1944-45 (London: HarperPress, 2008), 390.

38 Sevareid, Not So Wild a Dream, 388.

39 Ibid, 388-89. 
Michael Snape

that one factor which seems to have inflamed GIs against their German prisoners was their perceived manipulation of innate American decency. As Orval Eugene Faubus railed from Normandy in July 1944:

Almost all of them hope to go the States. The bastards have been fighting to destroy our way of life, our kindness, our generosity, our willingness to forgive, and have criticized us for those qualities. Yet they are the first to take advantage of when they can be useful... Like a heartless criminal who gives no mercy in the commission of his crimes but is the first to cry pitifully for mercy when he is caught... The Germans have shown no mercy to those they have conquered. I hope the guilty scoundrels get none when they are finally finished. ${ }^{40}$

Such sentiments were very publicly acted upon at Dachau in April 1945, where dozens of SS prisoners were summarily shot by their American captors, and even killed and dismembered by their former prisoners as GIs looked on. ${ }^{41}$ As Jewish army chaplain David Max Eichhorn shuddered:

We cried tears of hate. Combat hardened soldiers, Gentile and Jew, black and white, cried tears of hate. Then we stood aside and watched while the inmates of the camp hunted down their former guards... We stood aside and watched while these guards were beaten to death, beaten so badly that their bodies were ripped open and innards protruded... These evil people, it seemed to us, were being treated exactly as they deserved to be treated. To such depths does human nature sink in the presence of human depravity. ${ }^{42}$

Although these killings led an embarrassed Eisenhower to call for prosecutions, none ever materialised. ${ }^{43}$ In fact, and far from being exceptional, a mass of anecdotal evidence indicates that the shooting of German prisoners, or of Germans trying to surrender, was fairly commonplace among GIs in Northwest Europe.

While seldom brought to account in American military courts, and certainly different in order and magnitude to the ideologically driven and officially sanctioned mass-murder perpetrated by SS, Wehrmacht and German police units in Eastern Europe, ${ }^{44}$ such actions were far from being terrible aberrations. As the

40 Orval Eugene Faubus, In This Faraway Land (Conway, AR: River Road Press, 1971), 211.

41 Rick Atkinson, The Guns at Last Light: The War in Western Europe, 1944-45 (New York: Henry Holt \& Co., 2013), 612-14.

42 David Max Eichhorn, Greg Palmer and Mark S. Zaid, The GI's Rabbi: World War II Letters of David Max Eichhorn (Lawrence, KS: University Press of Kansas, 2004), 178.

43 Atkinson, Guns at Last Light, 613.

44 See, archetypically, Omer Bartov, Hitler's Army: Soldiers, Nazis, and War in the Third Reich (New York and Oxford: Oxford University Press, 1992) and Christopher R. Browning, Ordinary Men: Reserve Police Battalion 101 and the Final Solution in Poland (London: HarperCollins, 1992). 
future literary historian Paul Fussell darkly alluded, 'We were very hard on snotty Nazi adolescents'. Post-war novelist and memoirist Lester Atwell was more explicit, averring that “The boys ain't takin' any prisoners today" was a fairly common statement, and there was never any doubt as to its meaning. ${ }^{45}$ Even when captured alive, lethal treatment could be reserved for certain categories of enemy soldier. In light of the evidence available, the combat historian Peter S. Kindsvatter conceded that 'After Malmédy, SS troops attempted to surrender only at their own peril ${ }^{46}$ - a fact of no small significance given that the Waffen SS numbered more than 800,000 men by the end of the war. ${ }^{47} \mathrm{SS}$ or not, captured German snipers, who were regarded as an especially dangerous and malignant breed, were often made to dig their own graves, or urged to 'run for it' before being dispatched. ${ }^{48}$ For Atwell's $87^{\text {th }}$ Infantry Division, the climax to this spiral of retribution came at Tambach in southwest Germany, where a batch of German prisoners was shot in cold blood after surrendering. Significantly, the resulting prosecutions were aborted when the accused threatened to demonstrate that the brutality of their actions was entirely consistent with the treatment meted out to a captured German sniper by one of their own senior officers. ${ }^{49}$ Conceded by returning veterans, and described by more candid war correspondents such as Sevareid, this behaviour seems to have amounted to an open secret in post-war American society. For example, Ralph Luther Moellering, an American Lutheran pastor, stated in his 1956 book Modern War and the American Churches: 'Man's inhumanity to man is not limited to one nationality. War breeds hatred and ferocity. Who has been so cloistered from grim realities that he has heard nothing of the barbarities perpetrated by our own troops ? ${ }^{50}$ Besides the case of a conscripted German pastor and post-war missionary who had the initials of 'A drunken American soldier' carved on his back after being captured, Moellering reeled off another example: 'An American officer related the story of how his company captured a number of Germans, took them for a "walk", and caused them to "disappear". Because of the mood of vengeance which prevailed, he deemed it the better part of valor not to interfere. ${ }^{51}$ Significantly, these were not regarded as

45 Paul Fussell, Doing Battle: The Making of a Sceptic (Boston: Little, Brown \& Co., 1996), 124; Atwell, 1961, p. 131.

46 Kindsvatter, American Soldiers, 201.

47 I. C. B. Dear and M. R. D. Foot (eds), The Oxford Companion to the Second World War (Oxford and New York: Oxford University Press, 1995), 1046.

48 Lester Atwell, Private (London: Transworld Publishers, 1961), 261; Sevareid, Not So Wild a Dream, 407; Linderman, World within War, 119.

49 Linderman, World within War, 130-32; Atwell, Private, 1961, 261, 349-50, 383-84.

50 Ralph Luther Moellering, Modern War and the American Churches: A Factual Study of the Christian Conscience on Trial from 1939 to the Cold War Crisis of Today (New York: The American Press, 1956), 106. My italics.

51 Ibid. 
sensationalist or exceptionable claims by a marginal author, for in 1961 Moellering's book was recommended as 'excellent' in Nelson R. Burr's authoritative Critical Bibliography of Religion in America. ${ }^{52}$

Notwithstanding Eisenhower's expostulations after the scenes at Dachau, during the ground war against Germany and Italy it seems that senior American commanders could actively if tacitly discourage the taking of prisoners. On D Day for example, there seems to have been an understanding among the attacking American divisions that no prisoners were to be taken. Whether this was because of a lack of facilities for prisoners, or merely to sharpen the edge of aggression, or both, remains obscure ${ }^{53}$ However, outside Cherbourg in June 1944, a touch of the grotesque was employed to induce its German garrison to surrender. In the manner of a Wild West film, a German corpse was strapped to a horse chased into the city with the message: "All you sons-a-bitches are going to end up this way. ${ }^{54}$ German corpses could even be mutilated to obtain valuables. William B. Hanford, an artillery forward observer with the $103^{\text {rd }}$ Infantry Division, remembered how one combat medic used his scalpel to procure enough rings to buy a car after the war. As Hanford shrugged, [he] was a nice guy otherwise, but war was a crummy business, and the Articles of War took a beating from both sides. ${ }^{55}$

Antithetical to the Christian just war tradition, such manifestations of ruthlessness and revenge were widely and firmly condemned and resisted by those who sought to uphold its principles. Significantly, The Link (a widely distributed Protestant magazine for naval and military personnel) challenged the notion that Americans had to cultivate the same spirit of hatred that animated the Germans and Japanese. At the end of 1943, for example, it reprinted a piece from the magazine Church Management which argued that:

The Christian believes in justice but he deprecates hate. He will have no part in the propaganda that Americans must learn to hate their enemies more before they can secure decisive victory... We question the assumption that the best soldiers are those who hate. The best soldiers are those who believe that they have a divine commission to destroy a menace to society. They are not sadists; they take no delight in killing; they accept the disagreeable task as the only way to secure freedom in the world. They disagree with the pacifists because the latter do not feel that the will of God will ever command them to a service as distasteful as this. The Christian soldier does not so limit the will of God. ${ }^{56}$

52 Nelson R. Burr, A Critical Bibliography of Religion in America (Princeton, New Jersey: Princeton University Press, 1961), 4 vols, IV, 640.

53 Linderman, World within War, 129-30.

54 Atkinson, Guns at Last Light, 117.

55 William B. Hanford, A Dangerous Assignment: An Artillery Forward Observer in World War II (Mechanicsburg, PA: Stackpole Books, 2008), 54; Linderman, World within War, 127.

56 The Link, December 1943, 14. 
The following year, it quoted the words of Henry St. George Tucker, the Presiding Bishop of the Protestant Episcopal Church, who had roundly condemned the assumption that stoking a spirit of hatred and vengeance would help the United States prevail: 'if the New Testament has any one lesson to teach, it is that the end never justifies the means, that it is never legitimate to use a bad motive to produce a good end, because good ends can never be produced by bad motives' ${ }^{57}$

From conviction, and quite possibly in reaction to what they saw around them, many US Army chaplains sought to model and promote a spirit of charity towards a beaten enemy. In Tunisia, and in contrast to the mood Ernie Pyle detected among combat infantrymen, Presbyterian chaplain Eben Cobb Brink was anxious to demonstrate to crowds of dazed Axis prisoners 'that there were no enmities under the flag of blue with its cross of white' (that is, the insignia of the US Army chaplain). ${ }^{58}$ Likewise, Harry P. Abbott distributed comforts - 'writing paper, gum, and candy' - to all the wounded in a field hospital in Tunisia without distinction. ${ }^{59}$ In Abbott's words:

To [the chaplain], when the enemy is dead, in the hospital, or a prisoner of war and in captivity, he is no longer considered in the broadest sense, 'enemy'... The writer saw enemy prisoners weep sincerely when a few small kindnesses were shown. Some dying, appreciated a little kindness... It is only through this manner that we can promote a spirit of brotherhood in a world in which war shall thrive no more. Even on the battlefield there are times when the Christ-like spirit prevails over the gods of war. ${ }^{60}$

On occasion, such clemency could provoke the wrath of American commanders, whose priorities were naturally different. Charles E. Wilson, a chaplain's assistant in the $4^{\text {th }}$ Armored Division, recalled the fury of Lieutenant Colonel Creighton Abrams (a colourful figure who converted to Catholicism as overall commander of US forces in Vietnam) on discovering during the advance into Germany how a well-meaning chaplain had ushered German prisoners into the shelter of a nearby church:

Followed by an entourage of somber-faced officers, Abrams angrily pulled a muchchewed, unlit cigar from his mouth, and shouted with a resurrection voice of such irritated wrath, that every snoozing German soldier leaped [sic] to his feet and a strict attention... Abrams roared: 'What in hell is going on here? Get these god-damn sons of bitches out of

57 The Link, October 1944, 54.

58 Eben Cobb Brink, And God Was There (Philadelphia: The Westminster Press, 1944), 66.

59 Abbott, The Nazi '88', 131-32.

60 Ibid, 64-65. 
here right now. And get that damned Chaplain out of here before I shoot him on the spot! ${ }^{61}$

In justice to Abrams, the source of his wrath lay in the fact that his own men remained in the mud, sleet and snow while their erstwhile assailants enjoyed the considerable benefits of comparative warmth and shelter. ${ }^{62}$

However, such interventions could sometimes work in the chaplain's favour. Near Hanau in late March 1945, a battalion commander in the $90^{\text {th }}$ Infantry Division was physically prevented by a Catholic chaplain, Raymond P. Kerns, from killing a member of the Hitler Youth who had just surrendered. As Major John Cochran recalled:

I asked him if there were more like him in the town. He gave me a stare and said, 'I'd rather die than tell you anything.' I told him to pray, because he was going to die. I hit him across the face with my thick, heavy belt. I was about to strike him again when I was grabbed from behind by Chaplain Kerns. He said, 'Don't!' Then he took that crying child away. The Chaplain had intervened not only to save a life but to prevent me from committing murder. Had it not been for the Chaplain, I would have. ${ }^{63}$

A more significant intervention occurred in Sicily in 1943, after GIs of the $180^{\text {th }}$ Infantry Regiment massacred more than seventy Italian prisoners near the town of Biscari. These killings, like so many on a much smaller scale, could easily have slipped into oblivion but for its discovery by William E. King, the Southern Baptist senior chaplain of the $45^{\text {th }}$ Infantry Division. Primarily at King's instigation, an officer and sergeant were eventually court martialled for their role in these atrocities. However, punishments were mild because they pleaded in extenuation George S. Patton's inflammatory, pre-invasion exhortations. 'Old Blood and Guts', it transpired, had positively urged the inexperienced $45^{\text {th }}$ to 'kill devastatingly' and to earn a reputation as the 'Killer Division' ${ }^{64}$

To draw this discussion to a conclusion. More than seventy years after the end of the Second World War, and as American veterans of the most destructive conflict in history steadily pass away, a significant body of evidence - most of which is necessarily anecdotal - indicates that a popular and still dominant perception of America's war in Europe demands significant qualification, and that Americans should now be reconciled to a much murkier image of the United

61 United States Army Heritage and Education Centre, Carlisle, PA. Charles E. Wilson Papers, 'Frail Children of the Dust', 269-70.

62 Ibid, 270-71.

63 Ambrose, Citizen Soldiers, 439.

64 Rick Atkinson, The Day of Battle: The War in Sicily and Italy, 1943-1944 (New York: Henry Holt, 2007), 116-21; Burleigh, Moral Combat, 2010, 380; Margaret E. Wagner / David M. Kennedy et al, The Library of Congress World War II Companion (New York: Simon \& Schuster, 2007), 638-39. 
States in the Second World War. In other words, what Eisenhower styled in his 1948 memoir as a Crusade in Europe, should, like other crusades since Pope Urban II, be more widely understood for what it practically entailed. Whatever the depravity of the Third Reich, and however lofty their cause in the abstract, during the ground war in Europe GIs were responsible for a catalogue of crimes against German and Italian prisoners of war. Certainly, the US Army took hundreds of thousands of prisoners of war who survived capture and captivity - but, then again, so too did the Wehrmacht, especially in the western theatre of war, and in neither case did that preclude much more brutal modes of behaviour. Such conduct is all the more striking for a number of reasons. The continental United States was neither bombed nor occupied in the course of the war against Germany and Italy, and nor was the conflict inflamed by racial prejudice and hatred. Furthermore, and often notably reluctant to kill in the first instance, American combat soldiers were products of a society that saw itself in the inter-war years as one of the most Christian and peaceable in the world; they also typically professed that their experience of war had strengthened their faith in God. If so, their conduct in Europe, to say nothing of the Pacific, illustrates the perennial looseness of Christian (or Judeo-Christian) constraints in warfare, the mendacity that is inherent in mythologizing a nation's past, and the sheer fatuity of the view that any war is fundamentally 'good' rather than tragically necessary.

\section{References}

Abbott, Harry P.: The Nazi ' 88 ' Made Believers, Dayton, OH, The Otterbein Press, 1946. Addison, Paul / Crang, Jeremy A. (eds): Firestorm: The Bombing of Dresden 1945, London, Pimlico, 2006.

Ambrose, Stephen E.: Citizen Soldiers: The U.S. Army from the Normandy Beaches to the Bulge to the Surrender of Germany, June 7 1944-May 7, 1945, New York, Simon \& Schuster, 1998.

Atkinson, Rick: The Day of Battle: The War in Sicily and Italy, 1943-1944, New York, Henry Holt, 2007.

Atkinson, Rick: The Guns at Last Light: The War in Western Europe, 1944-45, New York, Henry Holt \& Co., 2013.

Atwell, Lester: Private, London, Transworld Publishers, 1961.

Bartov, Omer: Hitler's Army: Soldiers, Nazis, and War in the Third Reich, New York and Oxford, Oxford University Press, 1992.

Bassett, John T.: War Journal of an Innocent Soldier, New York, Avon Books, 1991.

Brink, Eben Cobb: And God Was There, Philadelphia: The Westminster Press, 1944. Brokaw, Tom: The Greatest Generation, New York, Random House, 1998.

Browning, Christopher R.: Ordinary Men: Reserve Police Battalion 101 and the Final Solution in Poland, London, HarperCollins, 1992.

Burleigh, Michael: Moral Combat: A History of World War II, London, HarperPress, 2010. 
Burr, Nelson R.: A Critical Bibliography of Religion in America (4 vols, IV.), Princeton, New Jersey, Princeton University Press, 1961.

Carlson, Alvin O.: He Is Able: Faith Overcomes Fear in a Foxhole, Grand Rapids, MI, Zondervan, 1945.

Daniel, Eugene L.: In the Presence of Mine Enemies: An American Chaplain in World War II German Prison Camps, Charlotte, NC, E.L. Daniel Jr, 1985.

Dear, I. C. B. / Foot, M. R. D. (eds): The Oxford Companion to the Second World War, Oxford and New York, Oxford University Press, 1995.

Eichhorn, David Max / Palmer, Greg / Zaid, Mark S.: The GI's Rabbi: World War II Letters of David Max Eichhorn, Lawrence, KS, University Press of Kansas, 2004.

Faubus, Orval Eugene: In This Faraway Land, Conway, AR, River Road Press, 1971. Fussell, Paul: Doing Battle: The Making of a Sceptic, Boston, Little, Brown \& Co., 1996. Hale, Wallace M.: Battle Rattle, Allen, TX, Timberwolf Press, 2004.

Handy, Robert T.: “The American Religious Depression, 1925-1935”, in: Church History 29, 1 (1960), 3-16.

Hanford, William B.: A Dangerous Assignment: An Artillery Forward Observer in World War II, Mechanicsburg, PA, Stackpole Books, 2008.

Hastings, Max: Bomber Command, London, Joseph, 1979.

Holland, James: Italy's Sorrow: A Year of War 1944-45, London, HarperPress, 2008.

Johnson, John E.: "The Faith and Practice of the Raw Recruit", in: Sperry, Willard Learoyd (ed.): Religion of Soldier and Sailor, Cambridge, MA, Harvard University Press, 1945.

Kindsvatter, Peter S.: American Soldiers: Ground Combat in the World Wars, Korea, and Vietnam, Lawrence, KS, University Press of Kansas, 2003.

Linderman, Gerald F.: The World within War: America's Combat Experience in World War II, New York, Free Press, 1997.

Marshall, S.L.A.: Men Against Fire: The Problem of Battle Command in Future War, New York, William Morrow \& Co., 1947.

Moellering, Ralph Luther: Modern War and the American Churches: A Factual Study of the Christian Conscience on Trial from 1939 to the Cold War Crisis of Today, New York, The American Press, 1956.

Murphy, Audie: To Hell and Back, New York, H. Holt, 1949.

Nance, Ellwood C.: Faith of Our Fighters, St. Louis, MO, Bethany Press, 1944.

Overy, Richard: The Bombing War: Europe, 1939-1945 (London: Allen Lane, 2013).

Putnam, Robert D. / Campbell, David E.: American Grace: How Religion Divides and Unites Us, New York, Simon and Schuster, 2010.

Pyle, Ernie / Kelly, Orr: Here is Your War: Story of GI Joe, Lincoln, NE, University of Nebraska Press, 2004.

Schrijvers, Peter: The Crash of Ruin: American Combat Soldiers in Europe During World War II, New York, New York University Press, 1998.

Sevareid, Eric: Not So Wild a Dream, New York, Atheneum, 1976.

Stouffer, Samuel A. et al: The American Soldier (2 vols, II.), Princeton, Princeton University Press, 1949.

Wagner, Margaret E. / Kennedy, David M. et al: The Library of Congress World War II Companion, New York, Simon \& Schuster, 2007. 


\section{Internet sources}

"Vietnam Veterans Against the War Statement by John Kerry to the Senate Committee of Foreign Relations", available online at: http://www2.iath.virginia.edu/sixties/ HTML_docs/Resources/Primary/Manifestos/VVAW_Kerry_Senate.html, [accessed 15 January 2018].

BBC: The rape of Berlin, available online at: http://www.bbc.co.uk/news/magazine-3252 9679, [accessed 3 August 2017].

IMDb: David Ayer, available online at: http://www.imdb.com/name/nm0043742/bio? ref_=nm_ov_bio_sm, [accessed 10 February 2016].

Interview: Arnold Spielberg, available online at: http://oralhistory.rutgers.edu/inter viewees/30-interview-html-text/146-spielberg-arnold, [accessed 3 August 2017].

Puhl, Jan: "Newly Discovered Film Shows Post-War Executions", in: Spiegel Online, 02. June 2010, available online at: http://www.spiegel.de/international/europe/massa cre-in-czechoslovakia-newly-discovered-film-shows-post-war-executions-a-698060. html, [accessed 3 August 2017].

Michael Snape, Department of Theology and Religion, Durham University, Abbey House, Palace Green, Durham, DH1 3RS, United Kingdom, e-mail: michael.snape@ durham.ac.uk

Citation: Snape, Michael: "Faith and Killing in the US Army in the Second World War: Some Perspectives from the European Theatre of Operations", in: Kallhoff, Angela / Schulte-Umberg, Thomas (eds.): Moralities of Warfare and Religion (J-RaT 2018 / 1) pp. 146-163.

Datum der Publikation: 16.07.2018 